DOI:10.22337/2587-9618-2018-14-૧-१००-०००

\title{
THE EXPERIENCE DIFFERENT OF PILING TESTING ON PROBLEMATICAL SOIL GROUND OF ASTANA, KAZAKHSTAN
}

\author{
Askar Zh. Zhussupbekov ${ }^{1}$, Yoshinori Iwasaki ${ }^{2}$, Abdulla R. Omarov ${ }^{1}$ \\ ${ }^{1}$ L.N. Gumilyov Eurasian National University, Astana, KAZAKHSTAN \\ ${ }^{2}$ Geo-Research Institute, Osaka, JAPAN
}

\begin{abstract}
At the present time, in Astana city is going on works by construction public transport system LRT (Light Railway Transport). LRT is an overhead road with two railway lines. The first stage of construction is including construction of overhead road (bridge) with $22,4 \mathrm{~km}$ length and 18 stations. The foundation of bridge is the bored piles with cross-section $1.0 \div 1.5 \mathrm{~m}$ and length $8 \div 35 \mathrm{~m}$. In these conditions, very important to control integrity of concrete body of each bored piles. For checking integrity applying two methods - Low Strain Method and Cross-Hole Sonic Logging. The aim of this paper is to discuss the advantages and disadvantages of each method using the examples of a real application. The article presents loading tests of large diameter and deep boring piles on the construction site in new capital city of the Republic of Kazakhstan. Finally, some recommendations for testing methods suitable for problematical ground conditions of Kazakhstan are introduced. Traditionally, pile load tests in Kazakhstan are carried out using static loading test methods. Static pile loading test is the most reliable method to obtain the load-settlement relation of piles. Results of static pile tests using the static compression loading test (by ASTM), static loading test (by GOST) and bi-direction static loading test (by ASTM) methods are presented in this paper. Experienced bored piles with length of $31.5 \mathrm{~m}$, diameter $1000 \mathrm{~mm}$. Hereafter the results of underground testing by the piles with the methods of vertical static tests of SLT, BDSLT and SCLT are presented, which had been made on Expo 2017 projects, buildings of Pavilion in Astana, Kazakhstan.
\end{abstract}

Keywords: cross hole section, testing by static vertical load, PIT, Osterberg or O-cell testing

\section{ОПЫТ ПРОВЕДЕНИЯ ИСПЫТАНИЯ СВАЙ В СЛОЖНЫХ ГРУНТОВЫХ УСЛОВИЯХ ГОРОДА АСТАНЫ, КАЗАХСТАН}

\author{
А.Ж. Жусупбеков ${ }^{1}$, Й. Ивасаки $^{2}$, A.Р. Омаров $^{1}$ \\ ${ }^{1}$ Евразийский национальный университет им. Л.Н. Гумилева, г. Астана, КАЗАХСТАН \\ ${ }^{2}$ Гео-исследовательский институт, г. Осака, ЯПОНИЯ
}

\begin{abstract}
Аннотация: В настоящее время в Астане ведутся работы по строительству системы общественного транспорта LRT (Light Railway Transport). LRT - это дорога на эстакаде с двумя железнодорожными линиями. Первый этап строительства включает в себя строительство верхнего пути (моста) длиной 22.4 километра и строительство 18 станций. Под опорной частью моста несущими подземными конструкциями являются буронабивные сваи сечением $1.0 \div 1.5$ метра и длиной $8 \div 35$ метров. В этих условиях очень важно контролировать целостность бетонного ствола каждой буронабивной сваи. Для проверки целостности свай применяются два метода - проверка сплошности бетона слабым импульсом и радиальный акустический каротаж. Целью данной работы является обсуждение преимуществ и недостатков каждого из этих методов на примерах их реального применения. Рассмотрены статические испытания свай большого диаметра и глубокого заложения на строительной площадке в новой столице Республики Казахстан. Представлены некоторые рекомендации по методам испытаний, подходящим для проблемных грунтов Казахстана. Традиционно, испытания с загружением свай в Казахстане проводятся методами статических испытаний. Статическое испытание свай является наиболее надежным методом получения достоверных результатов. В данной статье представлены результаты испытаний свай статическим испытанием на сжатие (по ASTM), статическим испытанием (по ГОСТу) и двунаправленным статическим испытанием (по ASTM). Были испытаны опытные буронабивные свай длиной 31.5 метров, диаметром 1000
\end{abstract}


миллиметров. Представлены результаты испытаний свай методами вертикальных статических испытаний SLT, BDSLT и SCLT, выполненных на проектах Международной специализированной выставки под эгидой Международного бюро выставок (МБВ) «ЭКСПО-2017» (Ехро 2017) для здания Павильона в Астане, Казахстан.

Ключевые слова: поперечное сечение, испытание статической вертикальной нагрузкой, PIT, Osterberg или O-cell testing

\section{INTRODUCTION}

In the spring of 2017, in Astana city was started works by construction public transport system LRT (shown figure 1 on Light Railway Transport). The cost of the project is about 1.9 billion dollars. Construction work produce a Chinese state-owned company «China Railway Asia-Europe Construction Investment Co». LRT is an overhead road with two railway lines. The first stage of construction is including construction of overhead road (bridge) with $22,4 \mathrm{~km}$ length and 18 stations [1]. Height of the bridge is $7 \div 14 \mathrm{~m}$ above the ground. Overhead road based on columns every 30 meters. The foundation of each column is include 4 or 6 bored piles with cross-section $1.0 \div 1.5 \mathrm{~m}$ and length $8 \div 35$ $\mathrm{m}$. Design bearing capacity of each bored piles is from 4500 to $8000 \mathrm{kN}$.

In order to reduce the time for construction and cost of piling works Chinese companies are use Chinese drilling rigs Zoomlion without casing. To maintain the walls of boreholes in sand and gravel soils using polymer slurry. Application of polymer slurry allow reducing time for drilling, allow to use less powerful drilling rigs and equipment, but at the same time increase the risk of collapsing soil during drilling or concreting piles. In these conditions, very important to control integrity of concrete body of each bored piles. For checking integrity of bored piles applying two methods - Low Strain Method and Cross-Hole Sonic Logging.

\section{SECOND MEGA PROJECT IN ASTANA EXPO-2017}

The complex of Expo-2017 will comprise 4,000 apartments, a new hotel, a Congress Hall, and an indoor city stretching from the Nazarbayev University to the center of Astana (the Capital of Kazakhstan). The exhibition area will involve the national pavilion of Kazakhstan, as well as international, thematic and corporate pavilions [2-4]. There will be located shopping malls, entertainment and service facilities as well. The total area of the exhibition stands at $174 \mathrm{hec}$ tares (Figure 2).

Static testing with Osterberg method (O-Cell testing) was carried out for the test of deep foundations at the site of the construction of this object. Four bored piles were subjected to static tests (O-cell testing- 2 piles and SCLT- 1 pile and SLT by GOST-1 pile) (see Figure 3).

The target of this tests was obtaining of bearing capacity of piles on problematical soils ground of Expo 2017 (Astana, Kazakhstan).

Based on the field description of the soils confirmed by the results of static sounding and laboratory tests, a division of the soils composing the site of prospecting for engineeringgeological elements in the stratigraphic sequence of their occurrence was carried out (Figure 4).

\section{METHOD OF STATIC COMPRESSION LOAD TEST BY ASTM (SCLT)}

Static compression loading testing was carried out in accordance to ASTM D 1143 [5]. Vertical static loading of piles using the SCLT method is one of the most widely used field test methods for soil used to analyze pile-bearing capacity. In the first cycle, the experimental pile was loaded to $100 \%$ of the design load, in the second cycle to $200 \%(12,000 \mathrm{kN})$. The holding time of intermediate loading stages was 30 minutes, unloading - 20 minutes [1-8]. 


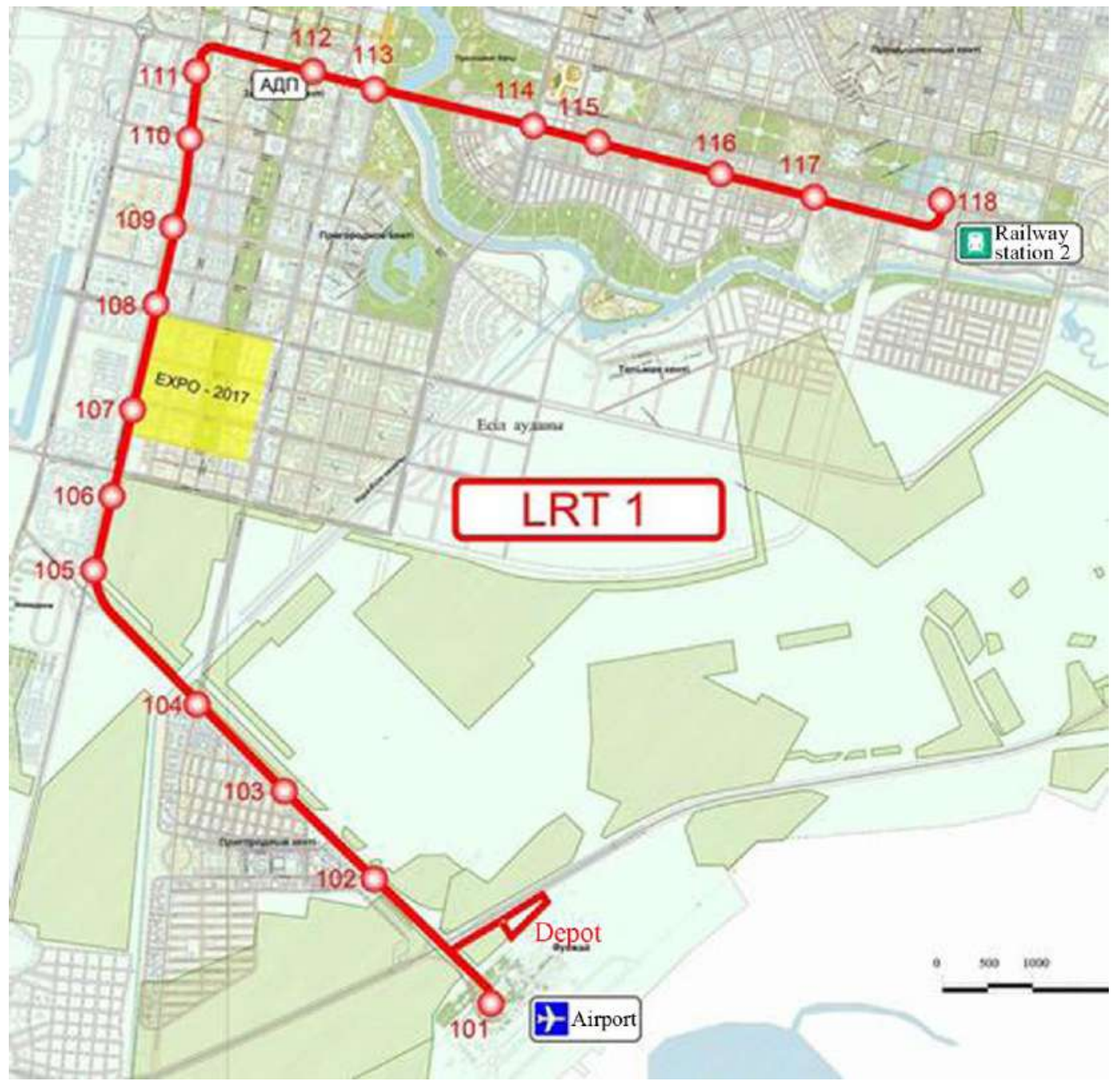

Figure 1. Map of First Line LRT in Astana, Kazakhstan.

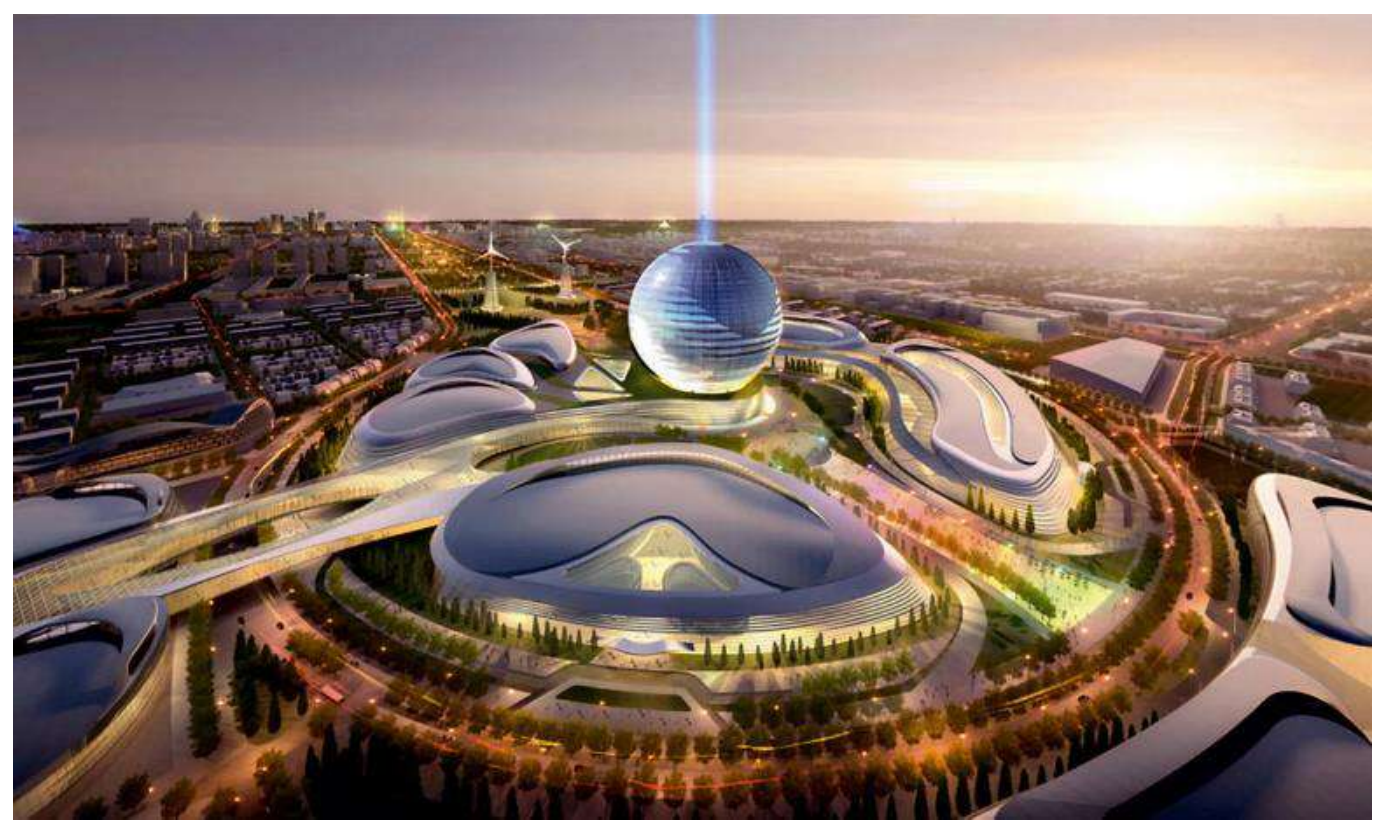

Figure 2. Project EXPO-2017 in Astana, Kazakhstan. 
The Experience Different of Piling Testing on Problematical Soil Ground of Astana, Kazakhstan

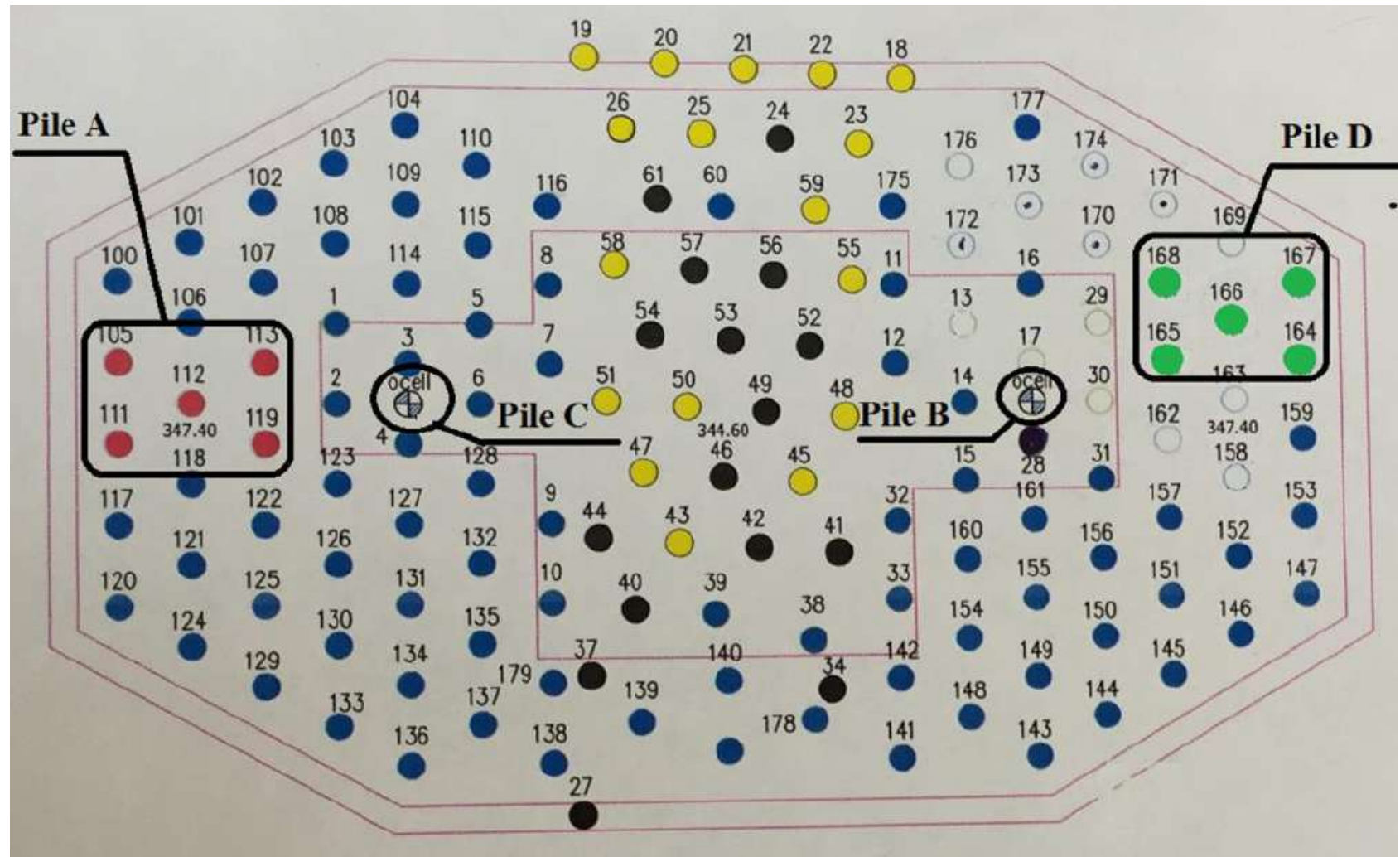

Figure 3. Plan of the pile foundations on construction site of EXPO-2017:

Pile A (SCLT by ASTM); Pile B (O-Cell-1); Pile C (O-Cell -2); Pile D (SLT by GOST).

\begin{tabular}{|c|c|c|c|c|c|c|}
\hline \multirow{2}{*}{$\begin{array}{l}\text { Number of engineering } \\
\text {-geological element }\end{array}$} & \multirow{2}{*}{ Soil nomenclature } & \multicolumn{5}{|c|}{ Design data of soil at soaking in natural state } \\
\hline & & E, MPa & p... & c-an & o.p. & $\mathrm{RQ} \mathrm{kPa}$ \\
\hline & Loams & 12.5 & 1.91 & 38 & 19 & . \\
\hline & Sands & 17.0 & 1.92 & 2.0 & 35 & . \\
\hline & Coarse sands & 21.0 & 1.92 & 1 & 38 & • \\
\hline & Gravel soils & 23.0 & - & . & . & 300 \\
\hline & Loams inclusions of gruse & 14.0 & 204 & 27 & 27 & . \\
\hline $\begin{array}{c}\nabla \nabla \nabla \nabla \nabla \nabla \\
\nabla \nabla \nabla(8) \nabla \nabla \nabla \\
\nabla \nabla \nabla \nabla \nabla \nabla\end{array}$ & Gruse solls & 36.4 & $=$ & , & . & 400 \\
\hline & Rock debris solls & $=$ & $=$ & ? & . & 450 \\
\hline
\end{tabular}

Figure 4. The physical and mechanical characteristics of the soils in Expo-2017 [1-4]. 
The time for maintaining peak loads was 120 and 240 minutes, respectively. The bearing capacity of the tested piles with static verticalpressing forces, at the above construction site, was $12000 \mathrm{kN}$. It should be noted that even with a maximum test load of $12000 \mathrm{kN}$, only the elastic operation of the pile in the ground is manifested, as evidenced by a slight residual soil settlement after unloading, which is $1.4 \mathrm{~mm}$ (Figure 10).

\section{METHOD OF BI-DIRECTIONAL STATIC LOAD TESTING (BDSLT)}

Pile tests by the Osterberg method are carried out at the pre-project stage, before the design and mass penetration of the piles begins. The method makes it possible to separately determine the bearing capacity of the ground along the tip and along the lateral surface of the pile. It is usually used for testing large or large drill or ramming piles.

When testing piles using the immersed jack, the O-cell power cell is installed directly into the body of the test pile. The power cell is a system of calibrated hydraulic jacks in a protective casing. It divides the test pile into two elements: the upper one, located above the power cell, and the lower one, located under the power cell.

The monitored load in the power cell (O-cell jack) is created by the hydraulic pressure from the oil station pump located on the surface and connected to the power cell by the oil pipe. The pressure is controlled by a precision electronic pressure gauge calibrated in the general scheme of the hydraulic system. In the process of increasing the load on the walls of the jack piston, the power cell opens. The result of this disclosure is the Settlement of the upper element of the pile upward and the lower element downward. The Settlement of the upper element is measured by rod strain gages mounted on the upper plate of the jack and by displacement sensors installed in the upper part of the steel pipe. The settlement of the lower element is measured by means of rod strain gages mounted on the lower plate of the power cell (O-cell jack).

The tests are continued until one of three conditions occurs: it will be that the limit of surface friction or lateral shear is reached; the ultimate load-bearing capacity will be reached; the maximum power of the power cell (O-cell jack) will be reached. Osterberg's method allows testing piles of large dimensions without the use of anchor piles, which reduces costs at the stage of geotechnical surveys [1-8].

According to the results of engineering and geological surveys, bored piles $31.5 \mathrm{~m}$ long and $1000 \mathrm{~mm}$ in diameter were used as foundations. In order to control and evaluate the compliance of the bearing capacity of piles on the ground, the design loads were field static tests by the Osterberg method (Figure 5).

The peculiarity of the $\mathrm{O}$-cell test method is that the load is applied not on the head of the pile, but in the body of the pile, where the jack (power cell) is installed, working in two directions. The power cell (O-cell jack) divides the test pile into two parts: the upper (upper test element UTE) and the lower (lower test element-LTE). The power cell (O-cell jack) is a system of calibrated hydraulic jacks combined into one module. The hydraulic jack is installed at a depth of $1 / 2$ the length of the pile $-16.8 \mathrm{~m}$. The power cell is connected by hydraulic hoses to the hydraulic pump located on the ground surface.

The figure 6 shows the results of strainmeasuring transducers. This figure 5 presents the load distribution along the length of the piles. The graph shows that even at maximum load, lateral resistance of the subsoil keeps the pile. Only a small part of the load accrues to the pile edge. The indicators of lateral resistance of the pile on the depth are presented in figure 6 [1-8]. When testing piles using the O-cell test, a maximum test load of $29000 \mathrm{kN}$ corresponds to a draft of $18.35 \mathrm{~mm}$ (for the O-cell-1, pile C) and - $14.40 \mathrm{~mm}$ (for the O-cell-2, pile D). During the testing of the piles, both elastic and plastic deformation of the soil was observed, due to a greater test load on the pile than in the SLT method. 
a) Top down

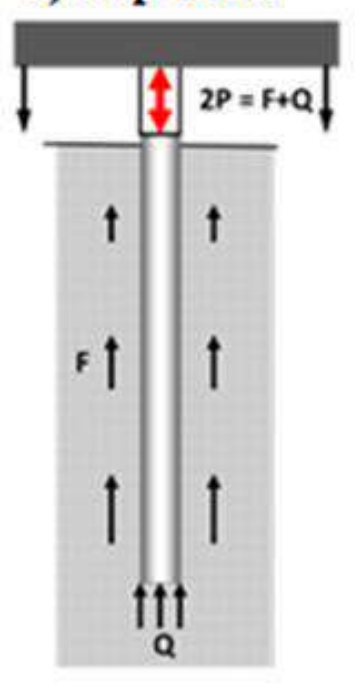

b) O-cell (Osterberg method)

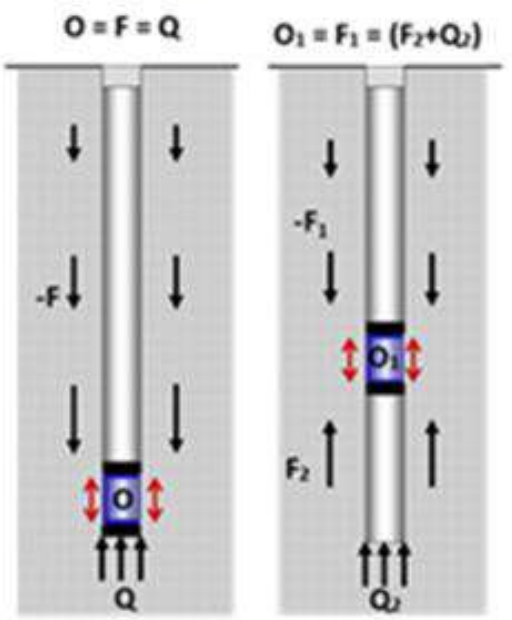

Figure 5. Scheme test load top downward and BDSLT.

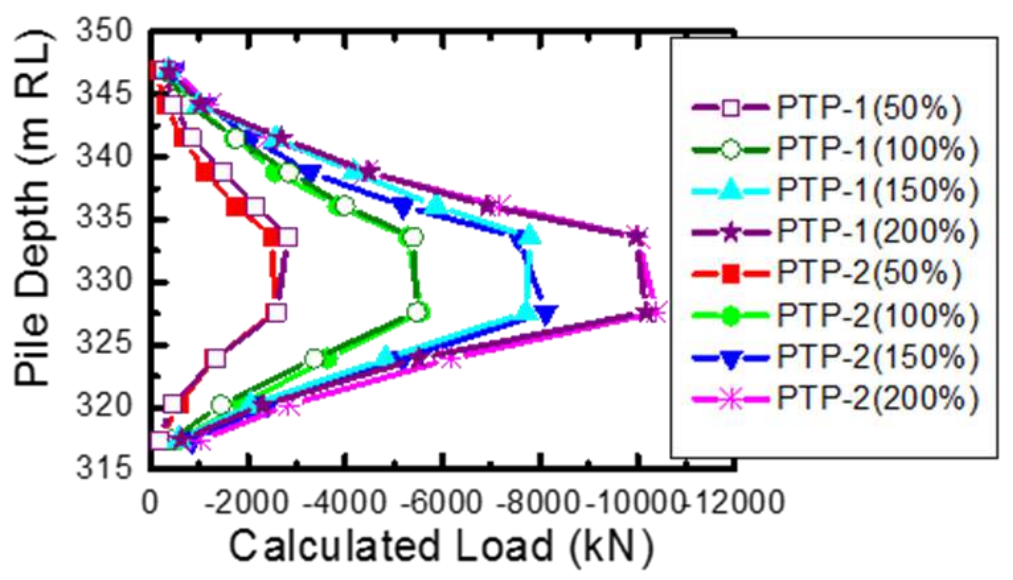

Figure 6. Calculated load distribution of piles (PTP-1 (O-cell-1) and PTP-2 (O-cell-2)).

\section{STATIC TESTS IN ACCORDANCE WITH THE REQUIREMENTS OF GOST}

Static tests of soils for bored piles are carried out in accordance to GOST 5686 [9]. Test was carried out after the pile concrete strength had attained more than $80 \%$ of the design value.

As part of the installation for soil testing, static pressing forces should include equipment:

- device for pile loading (jack);

- supporting structure or platform for perceiving reactive forces (for example, a system of beams with anchor piles or a platform);
- device for measuring the settlement of piles during the test (reference system with measuring instruments).

The bearing capacity of the tested piles with static vertical-pressing forces, at the above construction site, was $12000 \mathrm{kN}$ (Figure 10).

\section{PILE INTEGRITY TESTING}

Everybody with experience in reinforced concrete construction has encountered columns that, upon dismantling of the forms, exhibit air voids and honeycombing. Although these columns may have been cast with good-quality 
concrete, in properly assembled forms and with careful vibration, they still exhibit defects. Castin-situ piles are also columns, but instead of forms made of wood or metal we have a hole in the ground. This hole may pass through layers of dumped fill, loose sand, organic matter, and ground water, which may be fast flowing or corrosive. Obviously, such conditions are not conducive to a high-quality end product. The fact that on most sites we still manage to get excellent piles is only a tribute to a dedicated team that makes this feat possible: geotechnical engineer, structural engineer, quantity surveyor, contractor, site supervisor and quality control laboratory. This is obviously a chain, the strength of which is determined by the weakest link [10].

A flaw is any deviation from the planned shape and/or material of the pile. A comprehensive list of events, each of which can lead to the formation a flaw in a pile: use of concrete that is too dry, water penetration into the borehole, collapse in soft strata, falling of boring spoils from the surface, tightly-spaced rebars etc.

Therefore, we have to face the fact that on any given site some piles may exhibit flaws. Of course, not all flaws are detrimental to the performance of the pile. Only a flaw that, because of either size or location, may detract from the pile's load carrying capacity or durability is defined as a defect. The geotechnical engineer and the structural engineer are jointly responsible to decide which flaw comprises a defect.

The two techniques currently dominating pile integrity testing, namely the Low Strain Method and Cross-Hole Sonic Logging, both utilize sound waves.

\subsection{Low Strain Method (PIT).}

The low strain (sonic) method for the integrity testing of piles is aimed at routinely testing complete piling sites. To perform this test, a sensor (usually accelerometer) is pressed against the top of the pile while the pile is hit with a small hand-held hammer. Output from the sensor is analyzed and displayed by a suitable computerized instrument, the results providing meaningful information regarding both length and integrity of the pile [11].

\subsection{Interpretation results obtained by PIT Method.}

An assessment by this method can give a rapid and accurate appraisal of pile integrity. An integrity test will indicate when a pile should be investigated further but it cannot give information about any load carrying capacity of the pile.

Interpretation of the results obtained must take into account the specific pile circumstances, i.e. construction technique and localized soil conditions. An anomaly does not necessarily indicate a deficiency in the pile, but would certainly merit further investigation to establish the cause of the anomaly. Full interpretation of the signal responses must only be undertaken by fully trained personnel [11-15].

For interpretation ten classes are distinguished (Figure 7).

\subsection{Cross-Hole Sonic Logging.}

The Low Strain method belongs to the external test-methods, as it accesses only the top of the pile. Ultrasonic logging, on the other hand, is intrusive and necessitates the prior installation of access tubes (usually two or more) in the pile (Figure 8).

Before the test they have to be filled with water (to obtain good coupling) and two probes are lowered inside two of the tubes. One of these probes is an emitter and the other a receiver of ultrasonic pulses. Having been lowered to the bottom, the probes are then pulled simultaneously upwards to produce an ultrasonic logging profile. The transmitter produces a series of acoustic waves in all directions. Some of these waves do eventually reach the receiver [12].

The testing instrument then plots the travel time between the tubes versus the depth. As long as this time is fairly constant, it shows that there is no change in concrete quality. A sudden increase of the travel time at any depth may indicate a flaw at this depth [12]. 
The Experience Different of Piling Testing on Problematical Soil Ground of Astana, Kazakhstan

\begin{tabular}{|c|c|c|c|}
\hline PILE PROFILE & DESCRIPTION & Straight pile & Straight pile \\
\hline & Straight pile & Increased \\
\hline
\end{tabular}

Figure 7. Typical piles with respective reflectograms [11].
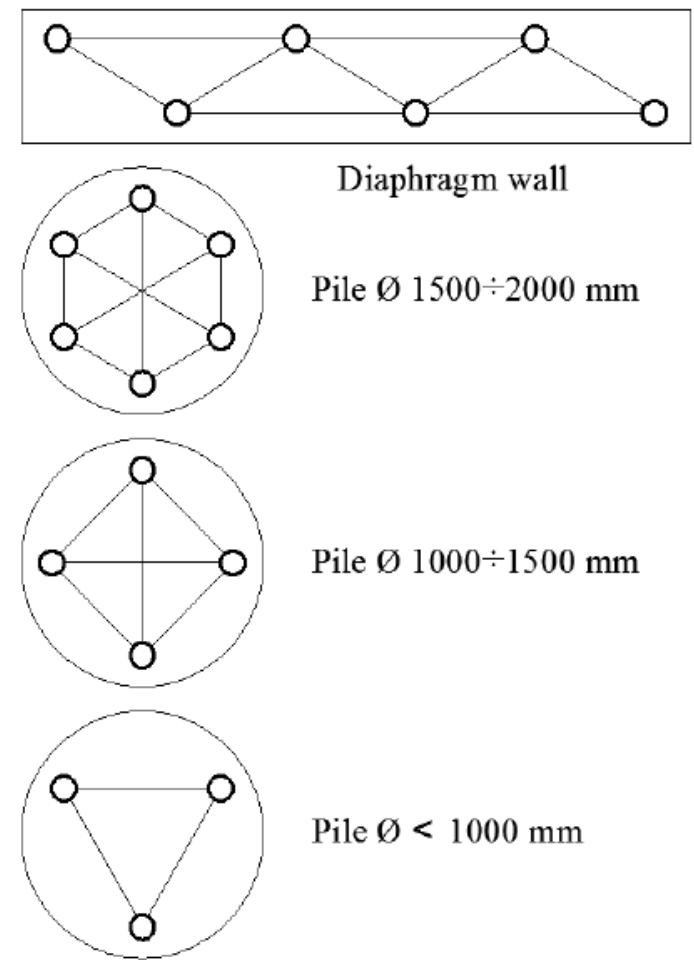

Figure 8. Typical Access Duct Configurations. 


\subsection{Cross-Hole Sonic Logging Results.} Usually the report includes presentation of Cross-Hole Sonic logs for all tested tube pairs including:

- Presentation of the traditional signal peak diagram as a function of time plotted versus depth.

- Computed initial pulse arrival time or pulse wave speed versus depth.

- Computed relative pulse energy or amplitude versus depth.

A Cross-Hole Sonic log will be presented for each tube pair. Defect zones, if any, will be indicated on the logs and their extent and location discussed in the report text. Defect zones are defined by an increase in arrival time of more than 20 percent relative to the arrival time in a nearby zone of good concrete, indicating a slower pulse velocity [12].

\subsection{Tomography by the data of Cross-Hole Sonic Logging.}

The same procedure, which is carried out in two dimensions on a single profile, can be used in three dimensions for the whole pile. In this case, the pile is divided into elementary voxels, or volume pixels, this process is usually called a tomography.

Tomography is a mathematical procedure that is applied to Crosshole Sonic Logging (CSL) data, providing the user with a visual image of a shaft's internal defects. The procedure involves solving a system of equations based on First Arrival Times (FAT) in order to calculate wave speeds at various points within the shaft. Tomography wave speeds distributed throughout the shaft are directly proportional to density, indicating concrete quality. PDI-TOMO is an extension of the CHA-W software designed for superior tomographic analysis results from CHAMP data with increased efficiency for the user (Figure 9).

\section{RESULTS OF FIELD TRIALS USING THE STATIC LOAD TEST AND OSTERBERG METHODS}

Figure 10 shows a comparison of the test results: the "load-sludge" curve obtained by the SCLT method and the equivalent "loadsettlement" curve determined by the O-cell method. For the comparative criteria of Pile A (SCLT by ASTM), Pile B (O-Cell-1), Pile C (OCell -2) and Pile D (SLT by GOST) results fixes settlements of 10 and $14 \mathrm{~mm}$ had been taken [16-19].

Table 1 presents a comparative analysis of the bearing capacity of piles, obtained by different methods in this research [19].

\section{CONCLUSIONS}

The cost of a quality control program for each construction site is very reasonable, and in any case much lower than the potential loss caused by an undetected defect of foundation. The Low Strain test is a powerful quality-control tool, not so expensive and need about one minute for application but we must never forget that it is not omnipotent. Since the sonic method is based on the use of stress-waves, it can identify only those pile attributes that influence wave propagation and have a fairly large size.

Cross-Hole Sonic Logging method more accurate, allow to estimate the size and position of cracks. Although the access tubes introduce an extra expense item, the cross-hole test compensates for this by allowing the testing equipment to approach potential flaws. An additional advantage of this test is the enhanced resolution: while the sonic test uses a wavelength of at least two meters, the cross-hole method utilizes ultrasonic frequencies, with typical wave lengths of 50 to $100 \mathrm{~mm}$. Since resolution is strongly dependent on the wave length, the cross-hole method enables us to detect much smaller flaws with high accuracy. 
The Experience Different of Piling Testing on Problematical Soil Ground of Astana, Kazakhstan

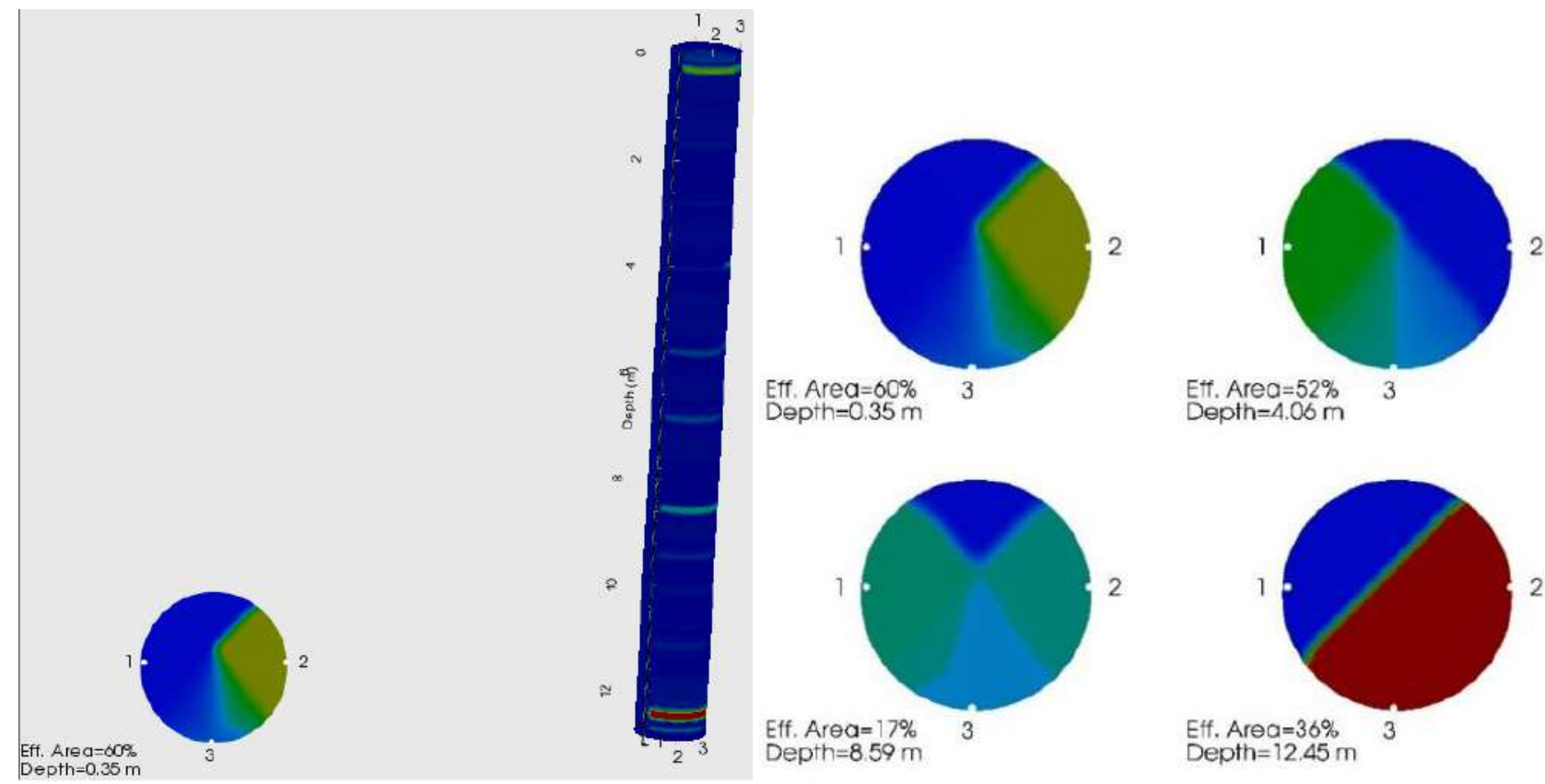

Figure 9. Three-dimensional visualization in PDI-TOMO software and Horizontal cross-sections of pile in PDI-TOMO software.

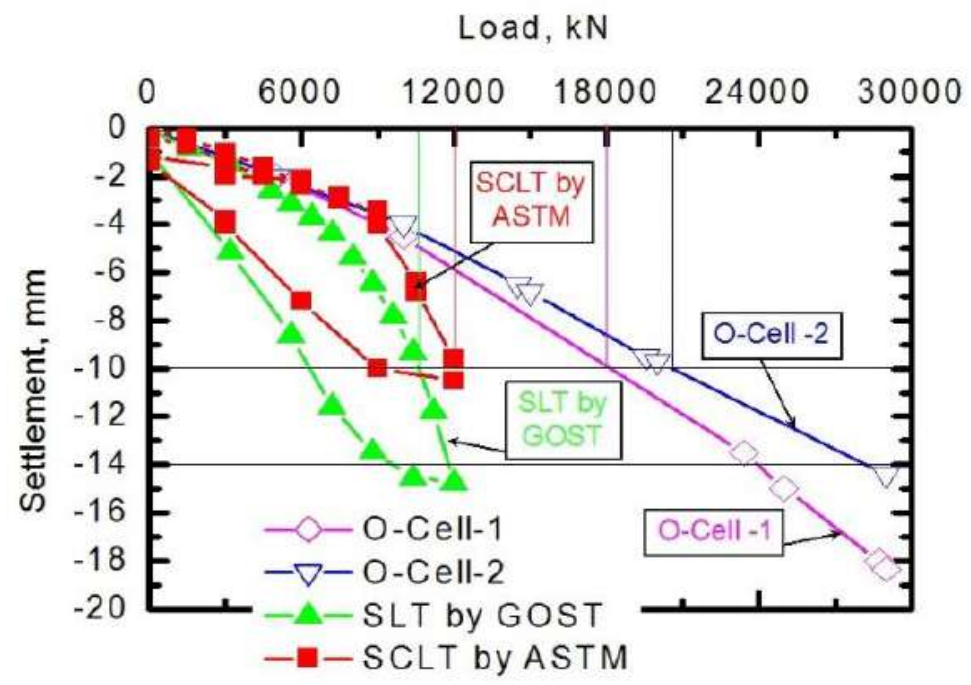

Figure 10. Comparison of test results carried out by SCLT, SLT and O-cell methods.

Table 1. Different Tests.

\begin{tabular}{|c|c|c|c|c|}
\hline ID & $\begin{array}{c}\text { Pile A } \\
\text { (SCLT } \\
\text { by ASTM) }\end{array}$ & $\begin{array}{c}\text { Pile B } \\
(\text { O-Cell-1) }\end{array}$ & $\begin{array}{c}\text { Pile C } \\
(\text { O-Cell -2) }\end{array}$ & $\begin{array}{c}\text { Pile D (SLT } \\
\text { by GOST) }\end{array}$ \\
\hline $\begin{array}{c}\text { The value of bearing capacity } \\
\text { of piles, } Q d\end{array}$ & $12000 \mathrm{kN}$ & $12000 \mathrm{kN}$ & $29000 \mathrm{kN}$ & $29000 \mathrm{kN}$ \\
\hline $\begin{array}{c}\text { Results fixes settlement } \\
-10 \mathrm{~mm}\end{array}$ & $11788 \mathrm{kN}$ & $18220 \mathrm{kN}$ & $20535 \mathrm{kN}$ & $10630 \mathrm{kN}$ \\
\hline $\begin{array}{c}\text { Results fixes settlement } \\
-14 \mathrm{~mm}\end{array}$ & - & $23985 \mathrm{kN}$ & $28385 \mathrm{kN}$ & $11814 \mathrm{kN}$ \\
\hline
\end{tabular}


The overlay of the curves showed that the convergence of the graphs is observed only at the initial stage of loading, then a change in the trajectory of the SLT curve, characteristic of the creeping stage of soil resistance, is observed, whereas the O-cell curve (at this stage of loading) is more characteristic of the elastic resistance of the soil.

According to the results of the SCLT unloading curve, elastic work of the soil is still evident. The reason for the abrupt change in the trajectory of the SCLT curve, which is not characteristic of the elastic work of the ground, is the holding time of the loading stages (lower compared to the O-cell test method), which can also explain the almost completely elastic work of the soil during O-cell tests.

When testing piles using the SLT method "from top to bottom", a design load of $6000 \mathrm{kN}$ corresponds to a draft of $2.09 \mathrm{~mm}$, a maximum test load of $12000 \mathrm{kN}$ is a draft of $10.51 \mathrm{~mm}$. It should be noted that even with the maximum test load, only the elastic operation of the pile in the ground is manifested, as evidenced by a slight residual soil sediment after unloading, which is $1.4 \mathrm{~mm}$.

When testing piles using the O-cell test, a maximum test load of $29000 \mathrm{kN}$ corresponds to a draft of $18.35 \mathrm{~mm}$ (for the PTP-1 pile) and $14.40 \mathrm{~mm}$ (for the PTP-2 pile). During the testing of the piles, both elastic and plastic deformation of the soil was observed, due to a greater test load on the pile than in the SLT method.

\section{REFERENCES}

1. Zhussupbekov A., Omarov A., Zhukenova G., Tanyrbergenova G. Pile Foundations of Mega Projects: New Railway Station and LRT in Problematical Soil Ground of Astana. // Transportation Geotechnics and Geoecology, TGG 2017, Procedia Engineering. Saint-Petersburg, Russia, 2017, Volume 189, pp. 511-518.

2. Zhussupbekov A., Omarov.A. Geotechnical and Construction of Pile Foundations in Difficult Soils Ground. // GeotechnikTag in München Geotechnik Zusammenwirken von Forschung und Praxis, 2016, München, pp. 41-48.

3. Zhussupbekov A., Omarov A., Morev I., Yergen A., Borgekova K. Analysis Results of Static and Dynamic Loads Tests of Pile Foundations in Constructions Site EXPO2017, Astana, Kazakhstan. // Proceedings of the 19th International Conference on Soil Mechanics and Geotechnical Engineering, Sep. 17 - 22, Seoul, Korea, 2017, pp. 30793082.

a. Zhussupbekov A., Omarov A. The Design of Foundations For the Mega Project "Expo 2017" in Astana, Kazakhstan. // "Building Technologies and Energy". Chapter 1. Cracow University of Technology. Cracow 2017, pp. 7-15.

4. ASTM D1143 / D1143M-07(2013)e1, Standard Test Methods for Deep Foundations Under Static Axial Compressive Load, ASTM International, West Conshohocken, PA, 2013, www.astm.org.

5. Zhusupbekov A.Zh., Lukpanov R.E., Omarov A.R. Experience in Applying Pile Static Testing Methods at the Expo 2017 Construction Site. // Soil Mechanics and Foundation Engineering, 2016, Vol. Issue 4, New-York, USA, pp. 251-256;

6. Zhusupbekov A.Zh., Lukpanov R.E., Omarov A.R. Bi-Directional Static Load Testing. // Proceedings of the Fourth GeoChina International Conference, Shandong, China, 25-27 July, 2016, pp. 35-42.

7. Zhusupbekov A.Zh., Omarov A.R. Modern Advances in the Field Geotechnical Testing Investigations of Pile Foundations. // The 15th Word Conference of Associated Research Centers for the Urban Underground Space. Saint-Petersburg, Russia, Procedia Engineering, Volume 165, 2016, pp. 88-95.

8. GOST 5686-94 Grunty. Metody Polevyh Ispytanij Svajami [Soils. Field test Methods by Piles]. Gersevanov Research Institute of 
Bases and Underground Structures (NIIOSP), Moscow, 1994.

9. Joram M.A. Pile Integrity Testing. Israel, 2009.

10. ASTM Standard D 5882 Standard Test Method for Low Strain Impact Integrity Testing of Deep Foundations. ASTM International, West Conshohocken, PA, 2000, www.astm.org.

11. ASTM Standard D 6760 Standard Test Method for Integrity Testing of Concrete Deep Foundations by Ultrasonic Crosshole Testing. ASTM International, West Conshohocken, PA, 2002, www.astm.org.

12. White B., Nagy M., Allin R. Comparing Cross-Hole Sonic Logging and Low-Strain Integrity Testing Results. // Proceedings of the 8th International Conference of Application of Stress Wave Theory to Piles, Lisbon, 2008, pp. 471-476.

13. Bungenstab F.C., Beim J.W. Continuous Flight Auger (CFA) Piles - A Review of the Execution Process and Integrity Evaluation by Low Strain Test. Argentina, Buenos Aires, IOS Press, 2015, pp. 414-421;.

14. Massoudi N., Teferra W. Non-Destructive Testing of Piles Using the Low Strain Integrity Method. // Proceedings of the Fifth International Conference on Case Histories in Geotechnical Engineering, New-York, NY, 2004, pp. 1-6.

15. Zhusupbekov A.Zh., Omarov A.R. Geotechnical and Construction Considerations of Pile Foundations in Problematical Soils. // Proceedings of the 8th Asian Young Geotechnical Engineers Conference (8 AYGEC), Kazakhstan, Astana, 2016, pp. 27-32.

16. Zhussupbekov A.Zh., Omarov A.R., Zhukenova G.A. The Experience in Applying of Static Load and O-Cell Pile Testing Geotechnologies in Problematical Soil Conditions of Astana. // International Mini symposium Chubu (IMS-CHUBU), Japan, Nagoya, Japanese Geotechnical Society Special Publication, 2017, Vol. 5, No. 2, pp. 167-171.
17. Zhussupbekov A., Omarov A., Zhukenova G. The Case Study of Testing Pile on Construction Site "EXPO-2017". // Proceedings of the 14th International conference on New Challenges in Geotechnical Engineering, ICNCGE-2017, Pakistan, Lahore, January 23, 2017, pp. 89-94.

18. Zhussupbekov A.Zh, Omarov A.R.,Borgekova K.B, Tanyrbergenova G., Ahazhanov S.B. Comparison of the Pile Testing Results on EXPO-2017 (Kazakhstan). // Proceedings of the International Conference "Geotechnics in Belarus: Science and Practice", Belarus, Minsk, October 23-26, 2018, pp. 163-174.

\section{СПИСОК ЛИТЕРАТУРЫ}

1. Zhussupbekov A., Omarov A., Zhukenova G., Tanyrbergenova G. Pile Foundations of Mega Projects: New Railway Station and LRT in Problematical Soil Ground of Astana. // Transportation Geotechnics and Geoecology, TGG 2017, Procedia Engineering. Saint-Petersburg, Russia, 2017, Volume 189, pp. 511-518.

2. Zhussupbekov A., Omarov.A. Geotechnical and Construction of Pile Foundations in Difficult Soils Ground. // GeotechnikTag in München Geotechnik Zusammenwirken von Forschung und Praxis, 2016, München, pp. 41-48.

3. Zhussupbekov A., Omarov A., Morev I., Yergen A., Borgekova K. Analysis Results of Static and Dynamic Loads Tests of Pile Foundations in Constructions Site EXPO2017, Astana, Kazakhstan. // Proceedings of the 19th International Conference on Soil Mechanics and Geotechnical Engineering, Sep. 17 - 22, Seoul, Korea, 2017, pp. 30793082.

4. Zhussupbekov A., Omarov A. The Design of Foundations For the Mega Project "Expo 2017" in Astana, Kazakhstan. // "Building Technologies and Energy”. Chapter 1. Cra- 
cow University of Technology. Cracow 2017, pp. 7-15.

5. ASTM D1143 / D1143M-07(2013)e1, Standard Test Methods for Deep Foundations Under Static Axial Compressive Load, ASTM International, West Conshohocken, PA, 2013, www.astm.org.

6. Zhusupbekov A.Zh., Lukpanov R.E., Omarov A.R. Experience in Applying Pile Static Testing Methods at the Expo 2017 Construction Site. // Soil Mechanics and Foundation Engineering, 2016, Vol. Issue 4, New-York, USA, pp. 251-256;

7. Zhusupbekov A.Zh., Lukpanov R.E., Omarov A.R. Bi-Directional Static Load Testing. // Proceedings of the Fourth GeoChina International Conference, Shandong, China, 25-27 July, 2016, pp. 35-42.

8. Zhusupbekov A.Zh., Omarov A.R. Modern Advances in the Field Geotechnical Testing Investigations of Pile Foundations. // The 15th Word Conference of Associated Research Centers for the Urban Underground Space. Saint-Petersburg, Russia, Procedia Engineering, Volume 165, 2016, pp. 88-95.

9. ГОСТ 5684-94 Методы полевых испытаний сваями. Межгосударственный стандарт. - М.: МНТКС, 1994.

10. Joram M.A. Pile Integrity Testing. Israel, 2009.

11. ASTM Standard D 5882 Standard Test Method for Low Strain Impact Integrity Testing of Deep Foundations. ASTM International, West Conshohocken, PA, 2000, www.astm.org.

12. ASTM Standard D 6760 Standard Test Method for Integrity Testing of Concrete Deep Foundations by Ultrasonic Crosshole Testing. ASTM International, West Conshohocken, PA, 2002, www.astm.org.

13. White B., Nagy M., Allin R. Comparing Cross-Hole Sonic Logging and Low-Strain Integrity Testing Results. // Proceedings of the 8th International Conference of Application of Stress Wave Theory to Piles, Lisbon, 2008, pp. 471-476.
14. Bungenstab F.C., Beim J.W. Continuous Flight Auger (CFA) Piles - A Review of the Execution Process and Integrity Evaluation by Low Strain Test. Argentina, Buenos Aires, IOS Press, 2015, pp. 414-421;.

15. Massoudi N., Teferra W. Non-Destructive Testing of Piles Using the Low Strain Integrity Method. // Proceedings of the Fifth International Conference on Case Histories in Geotechnical Engineering, New-York, NY, 2004, pp. 1-6.

16. Zhusupbekov A.Zh., Omarov A.R. Geotechnical and Construction Considerations of Pile Foundations in Problematical Soils. // Proceedings of the 8th Asian Young Geotechnical Engineers Conference (8 AYGEC), Kazakhstan, Astana, 2016, pp. 27-32.

17. Zhussupbekov A.Zh., Omarov A.R., Zhukenova G.A. The Experience in Applying of Static Load and O-Cell Pile Testing Geotechnologies in Problematical Soil Conditions of Astana. // International Mini symposium Chubu (IMS-CHUBU), Japan, Nagoya, Japanese Geotechnical Society Special Publication, 2017, Vol. 5, No. 2, pp. 167-171.

18. Zhussupbekov A., Omarov A., Zhukenova G. The Case Study of Testing Pile on Construction Site "EXPO-2017". // Proceedings of the 14th International conference on New Challenges in Geotechnical Engineering, ICNCGE-2017, Pakistan, Lahore, January 23, 2017, pp. 89-94.

19. Zhussupbekov A.Zh, Omarov A.R.,Borgekova K.B, Tanyrbergenova G., Ahazhanov S.B. Comparison of the Pile Testing Results on EXPO-2017 (Kazakhstan). // Proceedings of the International Conference "Geotechnics in Belarus: Science and Practice", Belarus, Minsk, October 23-26, 2018, pp. 163-174.

Askar Zhussupbekov, Professor, Dr.Sc., Head of Department of Civil Engineering, L.N. Gumilyov Eurasian National University; 13a, Kazhimukan st., Astana, Republic of 
Kazakhstan, 010010; phones +7(7172) 344796 (office), +7(7015) 118382 (mobile); fax +7 (7172) 709457;

E-mail: enu@enu.kz.

Yoshinori Iwasaki, Professor, Ph.D., Executive Director, Geo-Research Institute; Invited Professor, L.N. Gumilyov Eurasian National University; Honorary Professor, SaintPetersburg State University of Architecture and Civil Engineering; 4-3-2 Itachi-bori, Nishi-ku, Osaka 550-0012, Japan; phones +81-6-6941-8800 (office), +81-90-89381191 (mobile); fax +81-6-6941-8882;

E-mail: yoshi-iw@geor.or.jp.

Abdulla Omarov, Ph.D., L.N. Gumilyov Eurasian National University; 13a, Kazhimukan st., Astana, Republic of Kazakhstan, 010010; phone +7 (7172) 709500;

fax +7 (7172) 709457; e-mail: enu@enu.kz.

Жусупбеков Аскар Жагпарович, профессор, доктор технических наук, заведующий кафедрой «Проектирование зданий и сооружений», Евразийский национальный университет им. Л.Н. Гумилева; председатель ТС 305 (ISSMGE); президент Казахской геотехнической ассоциации; 010010, Казахстан, г. Астана, ул. Кажымукана 13a; тел.: +7(7172) 344796 (рабочий), +7(7015) 118382 (мобильный); факс +7 (7172) 709457;

E-mail: enu@enu.kz.

Ивасаки Йошинори, профессор, доктор философии (Ph.D.); исполнительный директор, Геоисследовательский институт; председатель АТC 19 Геопамятники культурного наследия (ISSMGE); приглашенный профессор, Евразийский национальный университет им. Л.Н. Гумилева; Почетный профессор СанктПетербургского государственного архитектурностроительного университета; 2-1-2, Отамае, Чуо-ку, Осака 540-008, Япония; тел.: +81-6-6941-8800 (рабочий), +81-90-8938-1191 (мобильный);

факс +81-6-6941-8882; e-mail: yoshi-iw@geor.or.jp.

Омаров Абдулла Рахметович, доктор философии (PhD); старший преподаватель кафедры «Проектирование зданий и сооружений», Евразийский национальный университет им. Л.Н. Гумилева; 010010, Казахстан, г. Астана, ул. Кажымукана 13a; тел.: +7(7172) 344796 (рабочий), +7(7011) 036642 (мобильный); факс: +7 (7172) 709457; e-mail: enu@enu.kz. 